\title{
Examination of the Development of New Bus Registrations with Alternative Powertrains in Europe
}

\author{
Jozef Gnap $^{1 *}$, Marek Dočkalik ${ }^{1}$ and Grzegorz Dydkowski ${ }^{2}$
}

${ }^{1}$ University of Žilina, Faculty of Operation and Economics of Transport and Communications, Univerzitná 8215/1, 01026 Žilina, Slovakia; Email: jozef.gnap@fpedas.uniza.sk, marek.dockalik@stud.uniza.sk

${ }^{2}$ University of Economics in Katowice, Department of Transport, 1. Maja 47, 40-287 Katowice, Poland; Email: grzegorz.dydkowski@ue.katowice.pl

\section{*Corresponding Author: Jozef Gnap}

Received: 18 January 2021; Revised: 15 February 2021; Accepted: 10 June 2021; Published: 21 October 2021

\begin{abstract}
The setting of minimum targets for EU member states to procure green vehicles within two reference periods ending in 2025 and 2030, should help to promote mobility with low, respectively zero emissions. The research results reveal that the V4 countries (Slovakia, Poland, the Czech Republic and Hungary) will find it very difficult to meet the set minimum targets for the share of ecological buses in the total number of buses included in the sum of all contracts subject to EU Directive 2019/1161 concluded from 2 August 2021. The share of buses with alternative powertrains in the V4 countries in 2019 was only $12.79 \%$ (with the minimum target being much higher). The Nordic countries are best placed to meet the minimum targets for the share of green buses (in 2019, the share of such buses was almost 19\%). The crisis caused by the COVID-19 pandemic, which has and continues to affect bus demand across Europe, may have a significant impact on meeting the minimum targets, especially by the end of the first reference period.
\end{abstract}

Keywords: Buses, alternative powertrains, ecology, sustainability

\section{Introduction and Literature Review}

The European Union is committed to achieving a sustainable, competitive, secure and decarbonised energy system. As a result, it has set ambitious targets, including the reduction of greenhouse gas emissions by at least $40 \%$ by 2030 compared to 1990 levels, to increase the share of renewable energy consumption by at least $27 \%$, to achieve at least $27 \%$ energy savings, as well as to increase energy security, competitiveness and sustainability within the Union [1]. The decarbonisation of the transport sector must be accelerated and it will therefore be necessary to steadily reduce greenhouse gas and air pollutant emissions from transport in order to reach zero levels by the middle of the century. This 
can be achieved through various policy initiatives, including measures that support the increased use of public passenger transport and the use of public procurement to promote clean vehicles. The purchase prices of vehicles with alternative powertrains are currently higher than vehicles with standard conventional powertrains. However, market forecasts suggest that the purchase prices of clean vehicles will fall [2].

Given that public expenditure on goods, works and services accounted for around 16\% of GDP in 2018, public authorities can stimulate and support markets for innovative goods and services through their public procurement policies. The setting of minimum targets for EU member states to procure green vehicles within two reference periods ending in 2025 and 2030, should contribute to political certainty in markets where investment in low and zero emission mobility is needed. In addition, the requirement that half of the minimum targets for buses procured during the reference periods be met through the procurement of zero-emission buses reinforces the EU's commitment to decarbonise the transport sector. It should be noted that trolleybuses are considered to be zeroemission buses provided that they are powered only by electricity or use exclusively a zero-emission powertrain. This puts cities like Bratislava, Prešov, Žilina and Banská Bystrica in the Slovak Republic at an advantage because they already have extensive trolleybus transport in place.

The introduction of these measures to promote green buses should neither lead to higher costs of compliance with the minimum procurement targets set out in EU Directive 2019/1161, thereby leading to higher ticket prices or a reduction in the range of public transport services, nor should it discourage the development of non-road services in the forms of trams, metros and trains [2-4]. The targets are expressed as minimum percentages of clean vehicles in the total number of road transport vehicles included in the sum of all contracts covered by EU Directive 2019/1161 concluded between 2 August 2021 and 31 December 2025 for the first reference period, and for the second reference period from 1st January 2026 until 31st December 2030 [2].

Due to the fact that the aforementioned directive is relatively new (d.d. 20 June 2019), not many articles have been published on the issue that is the subject of the research presented in this article. Most of the contributions examine the use of, for example, electric buses or buses that run on other alternative fuels and their contribution to reducing the impact of bus traffic on specific public passenger transport routes, in particular with regards to air quality [5-7]. In [8], the dynamics of competing fuels in two Swedish municipalities where electric buses have emerged, threatening incumbent biogas-based bus systems, are examined. While in Linköping, actors are resistant to the promise of electrification, in Malmö the shift to electrify urban buses has already begun. See also the case study of electric buses in Germany [9]. In [10], the complete course of fleet replacement using deterministic mixed integer programming is investigated. Bus fleet replacement is optimized by minimizing the Life Cycle Cost (LCC) of owning and operating a fleet of buses and required 
infrastructures while simultaneously reducing GHG emissions. More specific are those contributions that examine the need for an electrical system to recharge the batteries of electric buses if they were to be deployed in urban public transport. In [11], a method is put forward for determining the location of charging stations for electric vehicles, with the authors pointing out that in terms of effectiveness, the most suitable locations are $\mathrm{P}+\mathrm{R}$ (park and ride) car parks where transport by passenger car is combined with public passenger transport. In [12], the presented case study shows that a fully electric public bus fleet would require about $1.4 \mathrm{GWh}$ per day for revenue service, which represents approximately $1 \%$ of Singapore's daily electricity demand. In [13], a proposed multicriteria decisionmaking process using analytic hierarchy process (AHP) and the Technique for Order Preference by Similarity to Ideal Solution (TOPSIS) within the context of an electric bus in the centre of Ankara is evaluated. In [14], which focuses on direct and indirect carbon emissions, the economic value of the carbon emission reduction of bus electrification in relation to the operational lifecycle carbon footprint, with empirical data sourced from bus electrification in Macau, is studied. In [15], the driving cycle of an urban hybrid electric bus (HEB) in Zhengzhou, China is determined using a measurement system that integrates global positioning and inertial navigation functions to acquire driving data. In [16], the deployment of hybrid buses is analysed. In [17], the presented research provides a comprehensive novel framework for addressing uncertainty in whole life cycle costs and GHG emissions for the manufacture, use, maintenance and infrastructure phases of diesel and batterypowered electric buses. In [18], the focus is on Compressed Natural Gas (CNG) buses and their comparison with conventional diesel buses, which in countries such as Serbia have a dominant share. In [19], various energy performance indicators are presented and discussed with regards to the practical implications and applicability of policy support. In [20], a similar issue is addressed, but using a different methodology (Bass model) and partially other sources. In [21], the conducted analyses demonstrate that by 2050 only four EU members states will be able to achieve a $95 \%$ level of share of clean buses in their city bus transport fleets. It is likely that other countries may not achieve this even by 2050 . The environmental sustainability of the vehicle fleet change in public city transport of selected cities in Central Europe is important and therefore needs to be unequivocally supported from an urban perspective.

Other contributions, for example, address whether passengers are willing to pay extra for fares if green buses are used in urban public transport [22], look at the elasticity of demand for prices in public passenger transport [23], examine the competitiveness of public passenger transport before the COVID-19 pandemic [24], respectively analyse the initial effects on transport service provision and passenger demand during the crisis [25]. 


\section{Data and Methods}

In the the Slovak Republic, in the period 2015-2019, with the financial support of the European Union for public transport, the number of buses purchased with alternative powertrains (CNG, LPG and electricity) grew, thereby increasing their share in the vehicle fleet. We examined the data on buses in the Slovak Republic and Poland in more detail. Based on the processed data from the vehicle register of the Ministry of the Interior of the Slovak Republic, it was found that as of 14 October 2020 the average age of buses in class M2 and M2G compared to the previous year (17.71 years) was 18.32 years. Of this class of buses, which is intended to carry up to 22 passengers plus the driver, there are 896 in total in the Slovak Republic. As for the M3 and M3G class of buses, there are 7,422 of them with an average age of 11.14 years. This class of bus, which is also designed to carry up to 22 passengers plus the driver, is the most used in the Slovak Republic (see Table 1).

Table 1 Data on buses in the Slovak Republic as of 14.10.2020. Source: [26]

\begin{tabular}{lccc}
\hline & Number of buses & Average age & Percentage \\
\hline M2 and M2G & 896 & 18.32 & $10.77 \%$ \\
\hline M3 and M3G & 7,422 & 11.14 & $89.23 \%$ \\
\hline Overall & 8,318 & 11.91 & $100.00 \%$ \\
\hline \multicolumn{3}{l}{} \\
\hline Breakdown by powertrain: & $239(1 / 238)$ & 10.48 & \\
\hline CNG (M2/M3) & 1 & 3.27 & $0.55 \%$ \\
\hline LPG & 46 & 12.00 & $96.56 \%$ \\
\hline Electric (all M3) & 8032 & & \\
\hline Conventional powertrain & &
\end{tabular}

As of 14 October 2020, the average age of CNG + LPG buses was 10.48 years and that of electric buses only 3.27 years. The age of buses powered by alternative fuels is linked to the system of support for their procurement from the EU Structural Funds. So far, there has been no systematic planning of the change in the share by the self-governing regions as customers of suburban bus transport and urban public transport. At this point in time, the use of electric buses in the Slovak Republic is limited to public transport. The share of alternative powertrain buses in the Slovak Republic is still only $3.44 \%$. In Poland, the decrease in the number of new bus registrations was very significant. In the comparable period from January to October, there were 1,019 fewer new buses registered in Poland in 2020 than in 2019. In percentage terms, this represents a drop of 46.3\%. The decrease applies across all bus categories, whether mini, urban, suburban or tourist (see Table 2). No data were available on the number of registrations of new alternative fuel buses for the same period. In this case, the most significant factor for the decline in sales of new buses in Poland, but also globally, is the COVID-19 pandemic. 
Table 2 Registrations of new buses in Poland for the period January - October 2020. Source: [27]

\begin{tabular}{|c|c|c|c|c|c|c|c|}
\hline \multirow{2}{*}{\multicolumn{2}{|c|}{ Total weight }} & \multirow{2}{*}{$\begin{array}{c}\text { Bus } \\
\text { category }\end{array}$} & \multicolumn{2}{|c|}{ January - October 2020} & \multicolumn{2}{|c|}{ January - October 2019} & \multirow{2}{*}{$\begin{array}{c}\text { Year-on- } \\
\text { year } \\
\text { change }\end{array}$} \\
\hline & & & Number & Share & Number & Share & \\
\hline \multirow{3}{*}{$<8 \mathrm{t}$} & $<=3.5 \mathrm{t}$ & \multirow{3}{*}{ Mini } & 9 & $1.7 \%$ & 7 & $0.78 \%$ & $28.6 \%$ \\
\hline & $>3.5 \mathrm{t}$ & & 522 & $98.3 \%$ & 893 & $99.2 \%$ & $-41.5 \%$ \\
\hline & Overall & & 531 & $100 \% / 44.8 \%$ & 900 & $100 \% / 40.9 \%$ & $-41.0 \%$ \\
\hline \multirow{6}{*}{$>=8 \mathrm{t}$} & \multirow{4}{*}{$>3.5 \mathrm{t}$} & Urban & 539 & $82.5 \%$ & 951 & $73.0 \%$ & $-43.3 \%$ \\
\hline & & Suburban & 26 & $4.0 \%$ & 36 & $2.8 \%$ & $-27.8 \%$ \\
\hline & & Tourist & 88 & $13.5 \%$ & 311 & $23.9 \%$ & $-71.7 \%$ \\
\hline & & Other & 0 & $0.0 \%$ & 5 & $0.4 \%$ & $-100.0 \%$ \\
\hline & Overall & & 653 & $100 \% / 55.2 \%$ & 1303 & $100 \% / 59.1 \%$ & $-49.9 \%$ \\
\hline & Overall & & 1184 & $100 \%$ & 2203 & $100 \%$ & $-46.3 \%$ \\
\hline
\end{tabular}

In September 2020, a draft law on support for ecological road transport vehicles was submitted to the Slovak parliament. This draft law transposes Directive (EU) 2019/1161 of the European Parliament and of the Council of 20 June 2019 amending Directive 2009/33/EC on the promotion of clean and energy efficient road transport vehicles. The targets are expressed as minimum percentages of clean vehicles in the total number of road transport vehicles included in the aggregate of all contracts subject to EU Directive 2019/1161 concluded between 2 August 2021 and 31 December 2025. For the first reference period, the targets for buses in the M3 class for the Slovak Republic and Poland are 34\% and 32\%, respectively. For the second reference period, namely from 1 January 2026 to 31 December 2030, the targets are $48 \%$ and $46 \%$, respectively[2].

The above enables us to formulate the following research questions:

1) Is it realistic for the V4 countries to meet these commitments at the current pace of renewal of the vehicle fleet with ecological buses?

2) Which European countries are best placed to meet the minimum targets for the share of green buses?

\subsection{Development of New Bus Registrations with an Alternative Powertrain}

In Europe, the use of buses with elements of e-mobility technology is constantly increasing. In mid2018, there were an estimated 1,273 buses with e-mobility functions in Europe, which is 100\% more than in 2015. The current share of buses containing e-mobility elements is expected to increase from $10-12 \%$ of the current bus market to around $40 \%$ in 2025 , based on the current and projected order trend. The number of vehicles ordered in the first half of 2018 was equivalent to the total for 2017. In the year 2019, registrations of new electric buses in the EU increased by $170.5 \%$ from 594 units in 2018 to 1,607 units in 2019. Electrically chargeable vehicles accounted for $4.0 \%$ of total EU bus sales. Overall in 2019, 1,918 hybrid buses were registered across the European Union, or 59.7\% more 
than the year before. In contrast, no hybrid electric buses were registered at all in $13 \mathrm{EU}$ countries in 2019 [28]. Up to $6.2 \%$ of all new buses sold in the EU last year ran on alternative fuels, representing an increase of $67.9 \%$ to 2,504 registrations - nearly all of them being powered by natural gas. Figure 1 shows a visible increase in new bus registrations over 3.5 tonnes in total weight for electric buses, hybrid buses and also buses using alternative types of energy, namely natural gas, LPG, biofuels and ethanol. These statistics do not include data from some EU member states (Bulgaria, Croatia, Lithuania, and Malta) and from the United Kingdom.

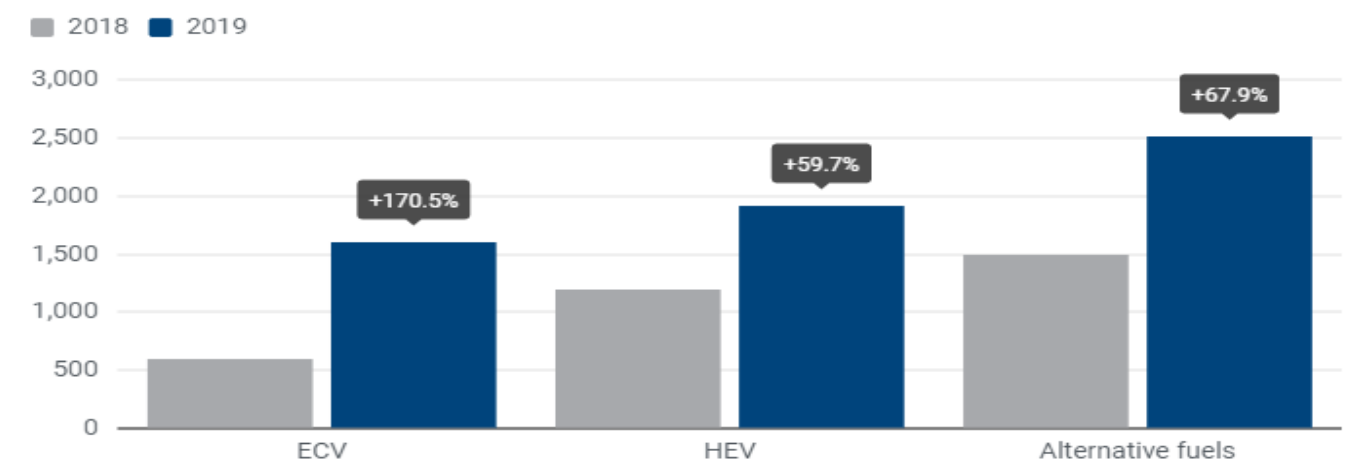

Fig. 1 Year-on-year increase in the number of new bus registrations with an alternative powertrain. Source: [28]

ACEA data shows that $15 \%$ of newly registered buses in 2019 were with an alternative powertrain (see Figure 2). Unfortunately, there are still big differences between EU countries. For example, in the Czech Republic in 2019, 25\% of new buses were already with an alternative powertrain (mainly natural gas) and in the Netherlands 55.2\%, but in the Slovak Republic only 3.9\%.

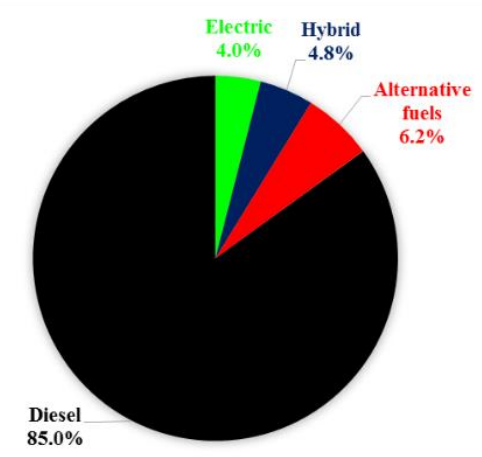

Fig. 2 Percentage breakdown of new bus registrations over 3.5 tonnes in the EU in 2019 by powertrain. Source: [28]

The development of the number of new bus registrations in Europe by powertrain is shown in Figure 3 for the period 2013-2019. As can be seen, from 2017, the curve for the number of new registered buses with conventional powertrains in Europe gradually and very gently starts to decrease. During the same period, a gradual increase in new buses with electric, hybrid or other alternative powertrains, such as natural gas or LPG, is also visible. This is largely due to the system of subsidies 
within the EU for measures to support green buses and the EU's commitment to meeting its environmental objectives.

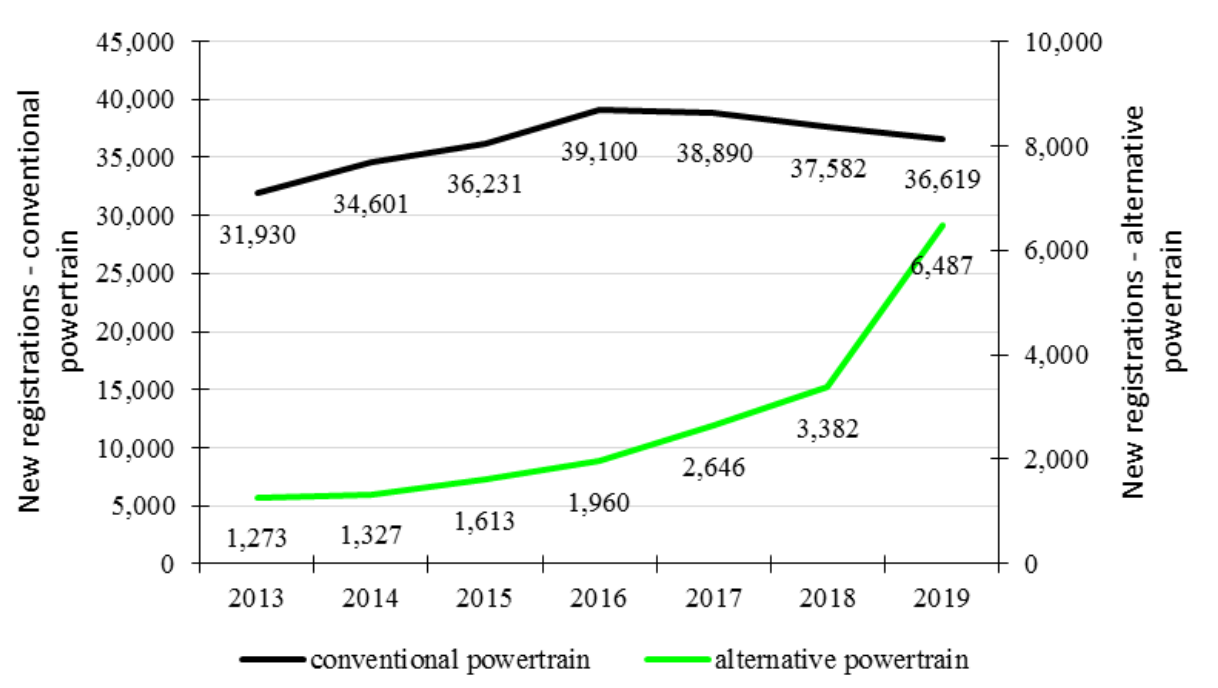

Fig. 3 Development of the number of new bus registrations in Europe.

Source: authors based on $[29,30]$

Especially in 2019, the increase in the number of new bus registrations with alternative powertrains was the highest compared to previous years.

\section{Results}

The number of new bus registrations in Europe in 2020 was mainly affected by the COVID-19 pandemic. Between January and November 2020 this was 27,251, which represents a significant drop from the same period in $2019(36,153)$ [31]. In relation to the research questions, the number of new bus registrations was examined by country or region in Europe. Based on the current approach to the use of alternative powertrains in road transport, European countries can generally be divided into three groups: V4 (Slovakia, Poland, Czech Republic and Hungary), the EU-15 and the Nordic countries (Norway, Sweden and Finland). As can been seen in Table 3, the most significant year-onyear increase in the share of new registered buses with alternative powertrains, in relation to the total niumber of new registrations, is in the Nordic countries.

Table 3 Number of new bus registrations by region of Europe. Source: authors

\begin{tabular}{ccccccc}
\hline Region & \multicolumn{2}{c}{$\begin{array}{c}\text { Number of new bus } \\
\text { registrations }\end{array}$} & \multicolumn{2}{c}{$\begin{array}{c}\text { Number of new } \\
\text { registrations - alternative } \\
\text { propulsion }\end{array}$} & $\begin{array}{c}\text { Percentage of newly registered } \\
\text { buses with alternative } \\
\text { propulsion }\end{array}$ \\
\hline year & 2018 & 2019 & 2018 & 2019 & 2018 & 2019 \\
\hline V4 & 4020 & 4526 & 351 & 579 & 8.73 & 12.79 \\
\hline EU 15 & 34195 & 34578 & 2894 & 5314 & 8.46 & 15.37 \\
\hline $\begin{array}{c}\text { Nordic } \\
\text { countries }\end{array}$ & 2408 & 4210 & 161 & 798 & 6.69 & 18.95 \\
\hline
\end{tabular}


Figure 4 shows the advantage the Nordic states have built up as a result of their systemic change to new bus procurement.
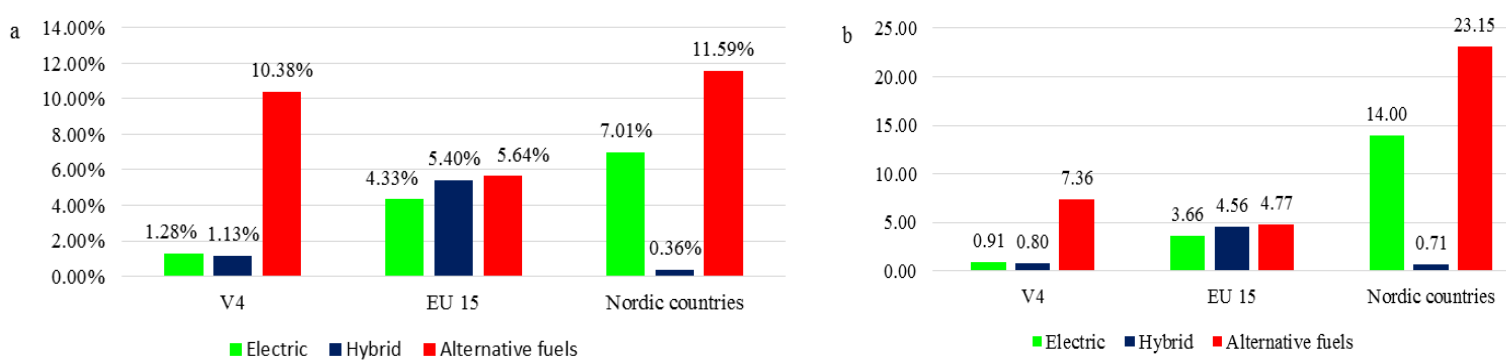

Fig. 4 a) Proportion of new bus registrations over 3.5 tonnes by powertrain (alternative powertrains only) in 2019; (b) The number of new bus registrations with alternative powertrains per million inhabitants (b). Source: authors

Figure $4 b$, in which the number of new bus registrations with alternative powertrains is calculated per million inhabitants, in many ways reflects the approach of states with regards to taking real steps to reduce the impact of transport on the environment and the health of the population. In the V4 countries, there was an increase in new bus registrations with alternative powertrains (natural gas, mainly LPG). In the Czech Republic, this is primarily due to new contracts for transport services in urban public transport in several cities which came into force in 2019. The procurement of new buses with alternative powertrains is certainly essential and important in meeting the EU's emissions reduction commitments. The decision to buy this type of bus may depend on several factors, such as the awareness of society about the need to look for ecological methods also in transport, the level of development of countries, the political strategies and direction of individual states, as well as GDP. For comparative purposes, the GDP per capita in 2019 of each European region was correlated against the percentage of new bus registrations with alternative powertrains. This shows that the higher the GDP per capita, the higher the number of new bus registrations with alternative powertrains.

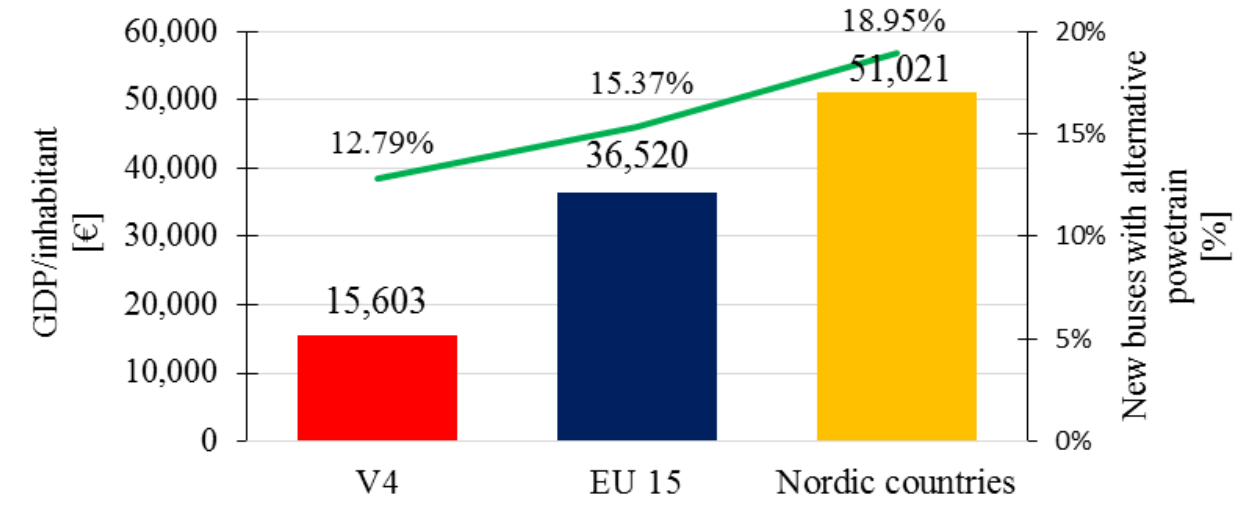

Fig. 5 Comparison of GDP per capita in 2019 and the share of new registered buses with alternative powertrains. Source: authors based on [32] 


\section{Discussion and Conclusion}

From the results of the research presented in this article, it can be said that the set targets for the total number of road transport vehicles included in the sum of all contracts subject to EU Directive 2019/1161 concluded from 2nd August 2021 to 31st December 2025, will be very difficult to meet, especially for the V4 countries. For the first reference period, the targets for buses in the M3 class for the Slovak Republic and Poland are 34\% and 32\%, respectively. For the second reference period, namely from 1 January 2026 to 31 December 2030, the targets are 48\% and 46\%, respectively. The Nordic countries are best placed to meet the minimum targets for the share of clean buses, with Sweden having set targets of $45 \%$ for the first reference period and $65 \%$ for the second (Finland $41 \%$ and $59 \%$, respectively). Although Norway is not an EU member state and does not have a minimum target for the number of buses with alternative powertrains, it is recognised as being one of the leaders in Europe. In 2019, for example, up to 157 electric buses were procured in Norway. By 2025, the country has forecast that the share of electric buses will be $77 \%$ [20]. In the Slovak Republic, the average age of CNG + LPG buses as of 14th October 2020 was 10.48 years, which represents a risk for the future. European countries with a higher GDP per capita also show a higher share of eco-bus registrations.

It is expected that with the growing number of purchases and further technological developments, especially in the field of batteries, purchase prices, especially of electric buses, will fall. In addition, the simpler powertrain structure should see operating costs fall in terms of maintenance and energy consumption. It is also necessary to guarantee the financing of the services provided and the implementation of an appropriate financial accounting policy so that carriers can procure, for example, additional batteries and new buses themselves in the next cycle. There are therefore assumptions that for this reason too, the pace of purchasing buses with alternative powertrains will increase. How the EU plans in this area with regards to the COVID-19 pandemic will need to be thoroughly examined at the end of this period. On the one hand, customers of bus services will not have sufficient funds to cover the necessary renewal of obsolete diesel buses, whilst on the other hand, we are aware of the need for faster renewal and the move towards the use of more environmentally friendly buses, which have the potential to significantly reduce the impact of their operation on air quality and the health of the population.

The change of the public transport bus fleet should be part of the Sustainable Urban Mobility Plans and the application of the Smart City principles [33]. It is also necessary to use innovative technologies and methods in public passenger transport in order to increase the efficiency of the deployment of green buses compared to the current situation [34-35]. 


\section{Acknowledgments}

This article was prepared with the support of the institutional research project of the Faculty of Operation and Economics of Transport and Communications, University of Žilina no.3/KCMD/2020 Research of selected aspects of transport services of cities and regions by passenger and freight transport.

\section{References}

[1] European Commission. (2011, March). White paper - Roadmap to a Single European Transport Area - Towards a Competitive and Resource Efficient Transport System. Retrieved March 27, 2020, from https://eur-lex.europa.eu/legalcontent/SK/TXT/PDF/?uri=CELEX:52011DC0144\&from=SK

[2] European Parliament. (2019, June). Directive (EU) 2019/1161 of the European parliament and of the council of 20 June 2019 amending Directive 2009/33/EC on the promotion of clean and energy-efficient road transport vehicles. Retrieved December 16, 2020, from https://eurlex.europa.eu/legal-content/EN/TXT/PDF/?uri=CELEX:32019L1161\&qid=1610109503291 $\&$ from $=\mathrm{SK}$

[3] Luupták, V., Hlatká, M. \& Kampf, R. (2018). Energy consumption and greenhouse gases emissions on relation Brno-Jihlava. Paper presented at the MATEC Web of Conferences, 235. DOI:10.1051/matecconf/201823500011.

[4] Rybicka, I., Stopka, O., L’upták, V., Chovancová, M. \& Droždziel, P. (2018). Application of the methodology related to the emission standard to specific railway line in comparison with parallel road transport: A case study. Paper presented at the MATEC Web of Conferences, 244. DOI:10.1051/matecconf/201824403002.

[5] Chang, Ch., Liao, Y. \& Chang, Y. (2019). Life cycle assessment of alternative energy types e including hydrogen e for public city buses in Taiwan. ScienceDirect. International Journal of Hydrogen Energy 44, 18472-18482. DOI: 10.1016/j.ijhydene.2019.05.073.

[6] Correa, G., Munoz, P.M. \& Rodriguez, C.R. (2019). A comparative energy and environmental analysis of a diesel, hybrid, hydrogen and electric urban bus. Energy 187, 115906. DOI: 10.1016/j.energy.2019.115906.

[7] Lupták, V., Stopková, M. \& Jeřábek, K. (2019). Comparative analysis in terms of environmental impact assessment between railway and road passenger transport operation: A case study. Paper presented at the Transport Means - Proceedings of the International Conference, October 2019 (pp. 1330-1334).

[8] Mutter, A. (2019). Obduracy and Change in Urban Transport - Understanding Competition Between Sustainable Fuels in Swedish Municipalities. Sustainability 11(21):6092. DOI: $10.3390 /$ su11216092.

[9] Rupp, M., Handschuh, N., Rieke, CH. \& Kuperjans, I. (2019). Contribution of country-specific electricity mix and charging time to environmental impact of battery electric vehicles: A case study of electric buses in Germany. Applied Energy 237, 618-634. DOI: 10.1016/j.apenergy.2019.01.059. 
[10] Islam, A. \& Lownes, N. (2019). When to go electric? A parallel bus fleet replacement study. Transportation Research Part D 72, 299-311. DOI: 10.1016/j.trd.2019.05.007.

[11] Csiszár, C., Csonka, B., Földes, D., Wirth, E. \& Lovas, T. (2019). Urban public charging station locating method for electric vehicles based on land use approach. J. Transp. Geogr. 2019, 74, 173-180. DOI: 10.1016/j.jtrangeo.2018.11.016.

[12] Gallet, M., Massier, T. \& Hamacher, T. (2018). Estimation of the energy demand of electric buses based on real-world data for large-scale public transport networks. Applied Energy 230, 344-356. DOI: 10.1016/j.apenergy.2018.08.086.

[13] Hamurcu, M. \& Eren, T. (2020). Electric Bus Selection with Multicriteria Decision Analysis for Green Transportation. Sustainability 12(7):2777. DOI: 10.3390/su12072777.

[14] Xu, X. \& Han, L. (2020). Operational Lifecycle Carbon Value of Bus Electrification in Macau. Sustainability 12(9):3784. DOI: 10.3390/su12093784.

[15] Peng, J., Jiang, J., Ding, F. \& Tan, H. (2020). Development of Driving Cycle Construction for Hybrid Electric Bus: A Case Study in Zhengzhou, China. Sustainability 12(17):7188. DOI: $10.3390 /$ su12177188.

[16] Blaž, J., Zupan, S. \& Ambrož, M. (2019). Study on the Eligibility of Introducing Hybrid-Drive Buses into the Public Passenger Transport. Stroj. Vestn. J. Mech. Eng. 65, 12-20. DOI: 10.5545/sv-jme.2018.5637.

[17] Harris, A., Soban, D., Smyth, B.M. \& Best, R. (2018). Assessing life cycle impacts and the risk and uncertainty of alternative bus technologies. Renewable and Sustainable Energy Reviews 97, 569-579. DOI: 10.1016/j.rser.2018.08.045.

[18] Ivkovic, I., Kaplanovic, S. \& Sekulic, D. (2019). Analysis of External Costs of CO2 Emissions For CNG Buses in Intercity Bus Service. TRANSPORT 34(5), 529-538. DOI: 10.3846/transport.2019.11473.

[19] Gustafsson, M., Svensson, N. \& Anderberg, S. (2018). Energy performance indicators as policy support for public bus transport - The case of Sweden. Transportation Research Part D (65), 697-709. DOI: 10.1016/j.trd.2018.10.008.

[20] Brdulak, A., Chaberek, G. \& Jagodziński, J. (2020). Development Forecasts for the ZeroEmission Bus Fleet in Servicing Public Transport in Chosen EU Member Countries. Energies 13(16):4239. DOI: 10.3390/en13164239.

[21] Konečný, V., Gnap, J., Settey, T., Petro, F., Skrúcaný, T. \& Figlus T. (2020). Environmental Sustainability of the Vehicle Fleet Change in Public City Transport of Selected City in Central Europe. Energies. 13(15):3869. DOI: 10:3390/en/13153869.

[22] Saz-Salazar, S., Feo-Valero, M. \& Vazquez-Paja, B. (2020). Valuing public acceptance of alternative-fuel buses using a Latent Class Tobit model: A case study in Valencia. Journal of Cleaner Production 261, 121-199. DOI: 10.1016/j.jclepro.2020.121199.

[23] Gnap, J., Konečný, V. \& Poliak, M. (2006). Demand elasticity of public transport. Ekon. Cas. 2006, 54, 667-684. Retrieved November 16, 2020, from https://www.researchgate.net/publication/292548426_Demand_elasticity_of_public_transport 
[24] Poliak, M., Poliaková, A., Mrníková, M., Šimurková, P., Jaskiewicz, M. \& Rafał, J. (2017). The Competitiveness of Public Transport. J. Compet. 81(9). DOI: 10.744/joc.2017.03.06.

[25] Konečný, V. \& Bridzíková, M. (2020). The Impact of the State of Emergency on the Supply of Services and Passenger Demand for Public Transport. LOGI - Scientific Journal on Transport and Logistics. 11(2), 56-65. DOI: 10.2478/logi-2020-0015.

[26] Ministry of Interior of the Slovak Republic (2020, October). Central Register of Vehicles of the Slovak Republic. Retrieved October 14, 2020.

[27] Polish Association of Automotive Industry, Warsaw. First registrations of new buses January to October 2020. Retrieved November 26, 2020.

[28] European Automobile Manufacturers Association. (2020, April). Medium and heavy buses (over $3.5 \mathrm{t}$ ) new registrations by fuel type in the European Union. Retrieved January 7, 2021, from https://www.acea.be/uploads/press_releases_files/ACEA_buses_by_fuel_type_fullyear_2019.pdf

[29] European Automobile Manufacturers Association. (2019, December). Vehicles in use Europe 2019. Retrieved December 18, 2020, from https://www.acea.be/uploads/publications/ACEA_Report_Vehicles_in_use-Europe_2019.pdf

[30] Eurostat. (2020, March). New registrations of motor coaches, buses and trolley buses by type of motor energy. Retrieved December 18, 2020, from https://appsso.eurostat.ec.europa.eu/nui/show.do?dataset=road_eqr_busmot\&lang=en

[31] European Automobile Manufacturers Association. (2020, November). New commercial vehicle registrations European Union. Retrieved January 07, 2021, from https://www.acea.be/uploads/press_releases_files/20201222_PRCV_2011_FINAL.pdf

[32] Eurostat. (2021, January). GDP and main components (output, expenditure and income). $\begin{array}{llll}\text { Retrieved January } & 04, & \text { from }\end{array}$ https://appsso.eurostat.ec.europa.eu/nui/show.do?dataset=nama_10_gdp\&lang=en

[33] Šulyová, D., Vodák, J. \& Koman, G. (2020). Implementation Smart City Concepts for Mobility, Case Study of World Logistic Models on the Smart Principles. LOGI - Scientific Journal on Transport and Logistics. 11(2), 110-119. DOI: 10.2478/logi-2020-0020.

[34] Stopka, O., Zitricky, V., Abramovic, A., Marinov, M. \& Ricci, S. (2019). Innovative Technologies for Sustainable Passenger Transport. Hindawi J. Adv. Transp., 2019, 4197246. DOI: $10.1155 / 2019 / 4197246$.

[35] Lupták, V., Drozdziel, P., Stopka, O., Stopková, M. \& Rybicka, I. (2019). Approach Methodology for Comprehensive Assessing the Public Passenger Transport Timetable Performances at a Regional Scale. Sustainability 1, DOI: 10.3390/su11133532. 